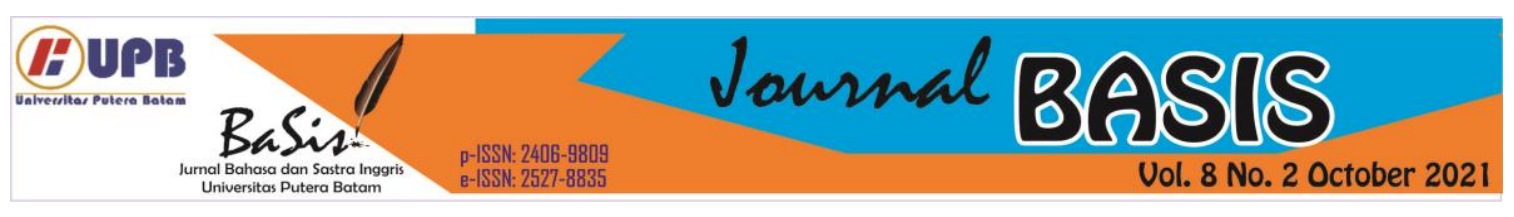

\title{
ILLOCUTIONARY ACTS UTTERED BY \\ THE MAIN CHARACTER IN FEAR OF RAIN MOVIE: PRAGMATIC APPROACH
}

\author{
Erni Hastuti ${ }^{1}$ \\ Universitas Gunadarma, Jakarta, Indonesia \\ erni@staff.gunadarma.ac.id \\ Hani Amalia Utami \\ Universitas Gunadarma, Jakarta, Indonesia \\ haniamaliau14@gmail.com \\ Teddy Oswari ${ }^{3}$ \\ Universitas Gunadarma, Jakarta, Indonesia \\ etoswari@staff.gunadarma.ac.id
}

\begin{abstract}
Speech acts are pragmatic elements that involve speaker and hearers in every conversation in which it has an illocutionary act. The purpose of the research was to find out the types and functions of illocutionary acts. This research used descriptive qualitative method. The data analyzed used the theory of Searle. The source of data is utterance of the main character in Fear of Rain movie. In this research, there are 355 data which contain types of illocutionary acts, such as assertive with 189 data (53\%) which consist of 7 functions (stating, informing, asserting, complaining, predicting, convincing, agreeing). Directives with 117 data (33\%) consisted of 7 functions (asking, commanding, requesting, advising, warning, suggesting, inviting). Commissive with 19 data (5\%) which consist of 3 functions (promising, refusing, and offering). Expressive with 30 data (9\%) consisted of 6 functions (thanking, apologizing, praising, greeting, blaming, and expressing anger). The most frequently type of illocutionary act is assertive because the utterance of the main character is believed to be true based on the fact

Keywords: illocutionary acts, pragmatic, speech acts
\end{abstract}

\section{INTRODUCTION}

Language is communication tool for people to establish a relationship in society in which it will be able to help everyone to express their feeling so it represents who they are and shows their identity in social group. The language used by humans as a means of communication with their environment is through speech. According to Sari (2017), the speech can be expressed through mass media, both oral and written. Communication activities are activities for humans to express themselves, convey information, ideas, and emotions, through word symbols. Words in language have more than one meaning, so the human are often confused.

Pragmatic discussed about the meaning of language that attached to the context. Yule (1996) stated that pragmatic is studying about the speaker meaning. Pragmatic can help us to build a good communication since it helps us to understand people's intention or purpose when they say something. One of pragmatic study is speech act in which it can be found in language communication. Speech act is the product of an utterance from a sentence in certain conditions and it is the smallest unit of language 
communication that determines the meaning of the sentence. According to Austin (1962) speech act is the act performed in uttering an utterance. There are three kinds of speech act namely locutionary act, illocutionary act, and perlocutionary act.

This research only focuses on the illocutionary act. Illocutionary act is the speaker's intention from the utterance which they said. Sefriana (2019) stated that illocutionary act does not only find in daily conversation but also in dialogue of movie. Movie is one of the ways to convey an utterance since there is dialogue convey by the character in the movie. We can understand the story line in the movie by analyzing the illocutionary acts. Cutting (2002) stated that illocutionary act is the most important classification in speech act since the illocutionary act is the main central of communication.

There are researches about illocutionary act conducted by some researchers in Indonesia. The research is done by Taufik (2016) analyze about types of illocutionary act which focused on direct and indirect speech act found in the movie. Then, Islami (2018) discussed about types of illocutionary act which used a Junior High School Student's Textbook as source of data. In addition, Siregar (2018) discussed about Expressive types of illocutionary act. Next, Sembiring (2019) discussed about the function of context of illocutionary act on Aladdin movie. This research is a pragmatic analysis of illocutionary acts using Searle's theory which limited to find out the types and the functions of illocutionary acts in utterance of the main character in Fear of Rain movie.

\section{LITERATURE REVIEW Pragmatics}

Pragmatics can also be said to be the science of linguistics which examines the intent which the speaker wants to convey to the interlocutor. The science of language is concerned with the analysis of what people mean by their utterances. According to Rustono (1999) Pragmatics is a branch of linguistics that studies the interrelationship between function and speech form. We also find pragmatics in every conversation. According to Rohmadi (2004) Pragmatics is a contextbound linguistic study. Context has a strong role in determining the speaker's intention in interacting with the interlocutor. So, it can be said that pragmatics is a study of linguistics that discusses the wearer in conversation which has the aim of conveying a certain purpose and involving a certain situation/context.

\section{Illocutionary Acts}

Illocutionary speech acts are a category in speech act theory. In illocutionary speech acts, the existence of a sentence or statement cannot be separated from a context. Illocutionary speech acts can also be said as an utterance made by the speaker to the speech partner with the aim that speech partner wants to take certain actions. Austin (1962) defines illocutionary acts as an utterance which has a certain force. A certain force means an action or function in every utterance uttered by the speaker. The use of illocutionary speech acts is to maintain polite and respectful actions from speakers and speech partners in communicating (Achsani, 2019). Ilocutionary speech acts can be said to be the most important act in the study and understanding of speech acts. Searle (1979) divided types of illocutionary acts into assertive, directive, commissive, expressive, and declarative 


\section{Research Method}

This research used descriptive qualitative method since the data form are utterances consist of words or sentence that is produced by the main character in Fear of Rain movie. According to Bodgan \& Biklen (2007) qualitative research are descriptive data in which the data is collected in the form of words or pictures rather than number.

Technique of collecting data as follows 1). downloaded Fear of Rain movie and Fear of Rain script; 2). watched the movie for several times to comprehend the story to get the context in every scene; 3 ). read the movie script; $4)$. collected the data that is spoken by the main character in Fear of Rain movie. The next step, Technique analyzing data is the process of analyzing the data that related to the research problem in order to discover the result of this research. The following steps of analyzing data such as 1). classified the types of illocutionary acts based on Searle's theory (1979) which uttered by the main character in Fear of Rain movie; 2). classified the function in each type of illocutionary acts which uttered by the main character in Fear of Rain movie; 3). presented the result and counted the percentage from the types of illocutionary acts in order to find out the most dominant type of illocutionary acts in Fear of Rain movie; 4). interpreted the reason why it is classified as the five types of illocutionary acts, 5). concluded the result of the research.

\section{RESULT AND DISCUSSION \\ 4.1 Result}

This research is found 355 data which have been classified into assertive, directives, commissive, and expressive and 23 functions from the main character's utterances in Fear of Rain movie. Those are assertive with 189 data $(53 \%)$ which is classified into the functions such as 65 data of stating,
54 data of informing, 18 data of asserting, 25 data of complaining, 6 data of predicting, 12 data of convincing, and 9 data of agreeing. Directives with 117 data $(33 \%)$ which is classified into the functions such as 64 data of asking, 35 data of commanding, 8 data of requesting, 1 data of advising, 2 data of warning, 6 data of suggesting, and 1 data of inviting. Commissive with 19 data (5\%) which classified into the function such as 3 data of promising, 11 data of refusing, and 5 data of offering. Expressive with 30 data (9\%) which is classified into the functions such as 1 data of thanking, 11 data of apologizing, 4 data of praising, 4 data of greeting, 2 data of blaming, and 8 data of expressing anger. Based on the result, the most frequently type of illocutionary acts is assertive with 189 data because the utterance of the main character is believed to be true based on the fact.

\subsection{Discussion}

The result of the research present that there are four types of illocutionary act found in the main character's utterances in Fear of Rain movie such as assertive, directives, commissive, and expressive. Each type of illocutionary acts is discussed below.

\section{Assertive}

Assertive illocutionary act is the speaker's utterances that is something in which they believe to be true and in accordance with the fact. The researcher found 189 data that has been classified into 7 functions. The data of each function as follow:

Stating

John: You remember that day?

Rain: Yeah. You and mom looked so happy.

01:02:25,971 --> 01:02:29,975 
The dialogue was taken when they were inside the bedroom, Rain saw an old picture of her with John and Michelle at the beach. Then John asked about the picture. It can be seen that Rain's utterances is assertive illocutionary act because she states that she thinks her mother and father look so happy on that picture. Stating is one of the functions from assertive illocutionary act. The datum is the line with the theory from Searle in which that assertive illocutionary act is the speaker's utterances based on the fact. Moreover, in the line with the research conducted by Violeta (2019) that stating is when people produced a statement which express something in word to state what they think about. These theories confirm that the datum is assertive illocutionary act.

Informing

Caleb: We just wait, I guess, and watch, figure out her schedule

Rain: She works Monday through Friday, from 7:00 to 4:00 and has a night class at HCC from 7:00 to 11:00. That's gonna be our prime time. $00: 47: 30,075 \rightarrow 00: 47: 39,418$

The dialogue above was taken when they tried to figure out how to get into Ms. McConnell's house. Caleb said that they must wait and figure out Ms. McConnell's schedule but Rain already knows Ms. McConnell's schedule. It can be seen that Rain's utterance is assertive illocutionary act because she gives an information. Informing is one of the functions from assertive illocutionary act. The datum is the line with the theory from Searle. That assertive illocutionary act is the speaker's utterance that is something in accordance with the fact. Moreover, in the line with the research conducted by Islami (2018) that informing is to tell someone about an information and the fact. These theories confirm that the datum is assertive illocutionary act.

Asserting

Michelle: Don't let me interrupt your date

Rain: It's not a date, Mom.

01:15:38,063 --> 01:15:40,966

The dialogue above was taken when Michelle caught Caleb kissed Rain. Michelle thinks that she was interrupting their date but actually they were not dating. It can be seen that Rain's utterance is assertive illocutionary act because she asserts to her mom that he and Caleb are not dating so there is no misunderstanding between her and Michelle. Asserting is one of the functions assertive illocutionary act. the datum is in the line with the theory from Searle. That assertive illocutionary act is the speaker's utterances that is something in which they believe to be true and in accordance with the fact. Moreover, in the line with the research conducted by Safira (2017) that asserting is when the speaker's statement asserts the truth of something. These theories confirm that the datum is assertive illocutionary act.

Complaining

Dr. Elyn: You realize if you choose to go off your medication, you're likely to end up in an institution where they'll force you to stay on it.

Rain: I'm so sick of this. 00:38:51,157 --> 00:39:01,801

The dialogue above was taken when Rain told her psychologist that the medicine was not working. It can be seen that Rain's utterance is assertive illocutionary act because she complains about the situation that happen to her. Complaining is one of the functions from assertive illocutionary act. the datum is in the line with the theory from 
Searle. That assertive illocutionary act is the speaker's utterances that is something in which they believe to be true and in accordance with the fact. Moreover, in the line with the research conducted by Violeta (2019) that complaining is saying something in dissatisfaction or annoyance with something. These theories confirm that the datum is assertive illocutionary act.

Predicting

Caleb: Why not?

Rain: You just said it could've been a cat. And if I'm wrong, they'll put me away.

01:07:57,737 --> 01:08:02,474

The dialogue above was taken when Caleb suggested to call the police but Rain did not want to call the police because Caleb said it could be a cat. It can be seen that Rain's utterance is assertive illocutionary act because she makes a prediction which is if she is wrong then they will send her to an institution. Predicting is one of the functions from assertive. The datum is in the line with the theory from Searle. That assertive illocutionary act is the speaker's utterances that is something in which they believe to be true and in accordance with the fact. Moreover, in the line with the research conducted by Violeta (2019) that predicting is to estimate something will happen in the future or will be a consequence of something. These theories confirm that the datum is assertive illocutionary act.

Convincing

John: It's normal, it's just, like, spruced up.

Rain: Dad, I'm sure it's fine.

00:12:08,287 --> 00:12:13,959

The dialogue above was taken when John made a strawberry pomegranate jam but Rain just wanted a normal peanut butter. It can be seen that Rain's utterance is assertive illocutionary act because she convinces her dad that she is fine with a normal peanut butter. convincing is one of the functions from assertive illocutionary act. the datum is in the line with the theory from Searle. That assertive illocutionary act is the speaker's utterances that is something in which they believe to be true and in accordance with the fact. Moreover, in the line with the research conducted by Violeta (2019) that convincing is to cause someone to believe that something is true. These theories confirm that the datum is assertive illocutionary act.

Agreeing

Michelle: I can actually feel myself

aging.

Rain: Yeah, you're right. A lot of wrinkles. Who knows how long that'll

take.

00:23:16,489 --> 00:23:24,096

The dialogue above was taken when Michelle said she felt aging and the Rain agreed with Michelle's statement. It can be seen that Rain's utterance is assertive illocutionary act because she agrees with Michelle's statement. Agreeing is one of the functions from assertive illocutionary act. The datum is in the line with the theory from Searle. That assertive illocutionary act is the speaker's utterance that is something in which they believe to be true and in accordance with the fact. Moreover, in the line with the research conducted by Violeta (2019) that agreeing is when the speaker's statement agree about something. These theories confirm that the datum is assertive illocutionary act.

\section{Directives}

Directives illocutionary act is that the speaker wants the hearer to do something. The researcher found 117 data that has been classified into 7 
functions. The datum of each function as follow:

Asking

Rain: Dad, who is that?

John: Oh, hey. It was nothing. It was

Phil.

00:20:33,926 --> 00:20:41,533

The dialogue above was taken when Rain heard John was on the phone talking to someone. Rain wondered who was talking to John on the phone. It can be seen that Rain's utterance is directives illocutionary act because the utterance is asking John to answer and tell her who was talking to him, and asking is one of the functions from directives illocutionary acts. The datum is in the line with the theory from Searle. That directive illocutionary act is when the speaker attempts to get the hearer to do something. Moreover, in the line with the research conducted by Ashari (2017) that asking is requesting an information through a question. These theories confirm that the datum is directives illocutionary act.

Commanding

John: Come here.

Rain: Get your fucking hands off me. 01:11:07,525 --> 01:11:11,596

The dialogue above was taken when John thought that Rain was just hallucinating about the scream and he asked whether she had been taking her medicine or not. Rain answered she had been already taking it but John did not believe her so John forced Rain to go to the kitchen to take her medicine. It can be seen that Rain's utterance is directives illocutionary act because she commands her dad to get his hand off from her, and commanding is one of the functions from directives illocutionary act. The datum is in the line with the theory from Searle. That directive illocutionary act is when the speaker attempts to get the hearer to do something. Moreover, in the line with the research conducted by Taufik (2016) that commanding is to make the hearer to do something. These theories confirm that the datum is directives illocutionary act.

\section{Requesting}

Rain: Can you stay with me?

Michelle: Of course, baby girl.

00:32:22,835 --> 00:32:25,838

The dialogue above was taken when Rain said that she heard a girl screaming from Ms. McConnell's house. So, John said they will go to Ms. McConnell's house tomorrow to check it and asked Rain to go back to sleep. Rain was still frightened so she said to Michelle Can you stay with me? It can be seen that Rain's utterance is directives illocutionary act because she requests Michelle to stay with her, and requesting is one of the functions from directives illocutionary act. The datum is in the line with the theory from Searle. That directive illocutionary act is when the speaker attempts to get the hearer to do something. Moreover, in the line with the research conducted by Violeta (2019) that requesting is asking politely toward the hearer to do something. These theories confirm that the datum is directives illocutionary act.

Advising

Rain: Mom, if I can get out and socialize, you can, too.

01:01:36,588 --> 01:01:39,224

The dialogue above was taken when Rain asked her mother what did she do that day but her mother did not answer her question. Then, Rain advised her mother "Mom, if I can get out and socialize, you can, too.". because her mother never gets out of the house and 
socialize as her and John did. It can be seen that Rain's utterance is directives illocutionary act because she gives an advice to her mother to try socialize with people, and advising is one of the functions from directives illocutionary act. The datum is in the line with the theory from Searle. That directive illocutionary act is when the speaker attempts to get the hearer to do something. Moreover, in the line with the research conducted by Safira (2017) that advising is to give an advice to the hearer to do something. These theories confirm that the datum is directives illocutionary act.

\section{Warning}

Michelle: Just wanted to see what you're seeing.

Rain: Be careful what you wish for. 00:51:19,872-->00:51:24,911

The dialogue above was taken when Michelle said that she wanted to see the girl which one at Ms. McConnell's house. Rain warned her mother because she did not even know whether the girl was real or not. And perhaps it would be just her terrifying hallucination. It can be seen that Rain's utterance is directives illocutionary act because she warns her mother, and warning is one of the functions from directives illocutionary act. The datum is in the line with the theory from Searle. That directive illocutionary act is when the speaker attempts to get the hearer to do something. Moreover, in the line with the research conducted by Azizah (2020) that warning is to give warning or reminder about something. These theories confirm that the datum is directives illocutionary act.

Suggesting

John: No, I don't...I don't have time.

Rain: I mean, no, you should go. You haven't cooked in forever.
00:20:47,974 --> 00:20:52,912

The dialogue above was taken when John Told Rain that his co-worker wanted him to help out a catering event. John was refusing his co-worker because he said that he did not have time to do that. But Rain suggested john to take the job. It can be seen that Rain utterance is directives illocutionary act because she suggests John to think of doing some action, and suggesting is one of the functions from directives illocutionary act. The datum is in the line with the theory from Searle. That directive illocutionary act is when the speaker attempts to get the hearer to do something. Moreover, in the line with the research conducted by Violeta (2019) that suggesting is introducing an idea or plan for the hearer to think about. These theories confirm that the datum is directive illocutionary act.

Inviting

Rain: Hey! Let's skip class and go back to her place.

00:53:27,432 --> 00:53:31,070

The dialogue above was taken when Rain invited Caleb to skip the class and go to Ms. McConnell's house to free the girl she kidnapped. It can be seen that Rain's utterance is directives illocutionary act because she invites Caleb to join her to skip class and go to Ms. McConnell's house, and inviting is one of the functions from directives illocutionary act. The datum is in the line with the theory from Searle. That directive illocutionary act is when the speaker attempts to get the hearer to do something. Moreover, in the line with the research conducted by Azizah (2020) that inviting is when the speaker attempts to get the hearer to join with the. These theories confirm that the datum is directives illocutionary act. 


\section{Commissive}

Commissive illocutionary act is the speaker commits themselves to do some action. The researcher found 19 data that has been classified into 3 functions. The example of each function as follow:

Promising

Rain: I'm gonna try to be better, I promise.

01:05:01,226 --> 01:05:03,228

The dialogue above was taken Rain saw her mother was crying over Rain's baby pictures. She thought that the mother was sad because of the situation that happen to Rain. It can be seen that Rain's utterance is commissive illocutionary act because she promises to her mother to be better, and promising is one of the functions from commissive illocutionary act. The datum is in the line with the theory from Searle. That commissive illocutionary act is when the speaker commits to do some future action. Moreover, in the line with the research conducted by Azizah (2020) that promising is when the speaker is committed to the hearer that they will make sure the statement they utter will be done later. These theories confirm that the datum is commissive illocutionary act.

\section{Refusing}

Caleb: try it again, pick one.

\section{Rain: Nope.}

01:14:47,947 --> 01:14:53,819

The dialogue above was taken when Caleb asked Rain to pick a tarot card but Rain was really panic about the situation so she said Nope. It can be seen that Rain's utterance is commissive illocutionary act because she makes a refuse to Caleb, and refusing is one of the functions from commissive illocutionary act. the datum is in the line with the theory from Searle. that commissive illocutionary act is when the speaker commits to do some future action. Moreover, in the line with the research conducted by Azizah (2020) that refusing is rejecting something from the hearer or disagree with the invitation of the hearer. These theories confirm that the datum is commissive illocutionary act.

\section{Offering}

Alexa: I... I feel like I can't breathe.

Rain: No, wait, I can help.

00:57:34,080 --> 00:57:38,818

The dialogue above was taken when Alexa was crying and could not breath so Rain said No, wait, I can help. In order to help her breath. It can be seen that Rain's utterance is commissive illocutionary acts because she offers help to Alexa, and offering is one of the functions from commissive illocutionary act. The datum is in the line with the theory from Searle. That commissive illocutionary act is when the speaker commits to do some future action. Moreover, in the line with the research conducted by Azizah (2020) that offering is the speaker's intention is offer the hearer some action. These theories confirm that the datum is commissive illocutionary act.

\section{Expressive}

Expressive illocutionary act is when the speaker expresses their feeling or attitude. The researcher found 30 data that has be classified into 6 functions. The example of each function as follow:

Thanking

Caleb: It's kind of nerdy, you know, but... I don't know, I guess I just like your brain.

Rain: I love it. Thanks

00:47:00,546 --> 00:47:13,258 
The dialogue above was taken when Caleb gave something he made for Rain. It can be seen that Rain's utterance is expressive illocutionary act because she said thanks to Caleb for the present, and thanking is one of the functions from expressive illocutionary act. The datum is in the line with the theory from Searle. That expressive illocutionary act is when the speaker expresses their feeling or attitude. Moreover, in the line with the research conducted by Siregar (2018) that thanking is the statement that contains thanking utterance. These theories confirm that the datum is expressive illocutionary act.

Apologizing

Rain: Oh, my... Sorry. I kind of crushed it.

Caleb: No. It's actually... It's for you. 00:46:33,720 --> 00:46:41,193

The dialogue above was taken when Rain accidentally sat on a tiny box so the box was almost crushed. It can be seen that Rain's utterance is expressive illocutionary act because she said an apology to Caleb for crushing the box, and apologizing is one of the functions from expressive illocutionary act. The datum is in the line with the theory from Searle. That expressive illocutionary act is when the speaker expresses their feeling or attitude. Moreover, in the line with the research conducted by Azizah (2020) that apologizing is when the speaker feels bad about something they do because the do something wrong. These theories confirm that the datum is expressive illocutionary act.

Praising

Rain: Best jelly I ever had.

John: It's jam, it's made from fruit pulp.

00:12:45,090 --> 00:12:48,628

The dialogue above was taken when John made breakfast at the kitchen for
Rain. She licked the jelly made by John and said Best jelly I ever had. It can be seen that Rain's utterance is expressive illocutionary act because she praises the jelly, and praising is one of the functions from expressive illocutionary act. The datum is in the line with the theory from Searle. That expressive illocutionary act is when the speaker expresses their feeling or attitude. Moreover, in the line with the research conducted by Putri (2019) that praising is when the speaker expresses their amazement to the hearer. These theories confirm that the datum is expressive illocutionary act.

\section{Greeting}

Caleb: Hey.

Rain: Hey.

00:58:13,686 --> 00:58:14,920

The dialogue above was take when Caleb came to Rain and said Hey. It can be seen that Rain's utterance is expressive illocutionary act because she greets her friend, and greeting is one of the functions from expressive illocutionary act. The datum is in the line with the theory from Searle. That expressive illocutionary act is when the speaker expresses their feeling or attitude. Moreover, in the line with the research conducted by Islami (2018) that greeting is when the speaker welcomes the hearer with particular words such as Hi, Hello, Good Morning. These theories confirm that the datum is expressive illocutionary act.

\section{Blaming}

Rain: This is your fault in the first place! I wouldn't be dealing with any of this, if you hadn't made me sick! I'm... I hate you.

01:21:28,681 --> 01:21:34,353

The dialogue above was taken when Rain blames her mother that she thought the cause of her mental illness with 
terrifying hallucination was her mother fault. It can be seen that Rain's utterance is expressive illocutionary act because she blames her mother that the cause of her sickness is her mother, and blaming is one of the functions from expressive illocutionary act. The datum is in the line with the theory from Searle. That expressive illocutionary act is when the speaker expresses their feeling or attitude. Moreover, in the line with the research conducted by Putri (2019) that blaming is when the speaker blames the hearer about something. These theories confirm that the datum is expressive illocutionary act.

Expressing Anger

John: Who gives a shit whether she's been in her own attic or not?

Rain: Well, you never believe me! You listen to someone you don't even like. 00:35:16,676 --> 00:35:20,479

The dialogue above was taken when Rain was mad at John because he did not believe her so she was yelling at John. It can be seen that Rain's utterance is expressive illocutionary act because she is expressing her anger by yelling at John, and expressing anger is one of the functions from expressive illocutionary act. The datum is in the line with the theory from Searle (1979). That expressive illocutionary act is when the speaker expresses their feeling or attitude. Moreover, in the line with the research conducted by Violeta (2019) that expressing anger is when the speaker expresses resentment for unpleasant treatment is a strong emotion because the speaker thinks that the hearer has behaved in an unfair, cruel, or unacceptable way. These theories confirm that the datum is expressive illocutionary act.

\section{CONCLUSION}

In this research is found 355 data from the main character's utterances in Fear of Rain movie that have been classified into types of illocutionary act. There are four out of five types of illocutionary acts from the main character's utterances in Fear of Rain movie. They are assertive with 189 data (53\%), directives with 117 data $(33 \%)$, commissive with 19 data (5\%), and expressive with 30 data (9\%). Each type of illocutionary acts has different function. The researcher found 23 functions form Rain's utterances the main character in Fear of Rain movie. Assertive has 65 data of stating, 54 data of informing, 18 data of asserting, 25 data of complaining, 6 data of predicting, 12 data of convincing, and 9 data of agreeing. Directives has 64 data of asking, 35 data of commanding, 8 data of requesting, 1 data of advising, 2 data of warning, 6 data of suggesting, and 1 data of inviting. Commissive has 3 data of promising, 11 data of refusing, and 5 data of offering. Expressive has 1 data of thanking, 11 data of apologizing, 4 data of praising, 4 data of greeting, 2 data of blaming, and 8 data of expressing anger.

\section{REFERENCES}

Achsani, F. (2019). Tindak Tutur Direktif dan Implikatur Konvensional dalam Wacana Meme Dilan. Imajeri: Jurnal Pendidikan Bahasa Dan Sastra Indonesia, 1(2), 1-10.

Ashari, R. E. (2017). A Pragmatic Analysis of Illocutionary Acts Found in Finding Nemo Movie and Its Application in Teaching Speaking at The Twelfth Grade of Senior High School. Purworejo: Purworejo Muhammadiyah University. 
Austin, J. (1962). How To Do Things With Words. London: Oxford University Press.

Azizah, W. N. (2020). An Analysis of Illocutionary Acts Used by Main Character in The Sherlock Holmes Movie: The Empty Hearse. Thesis. Tulungagung: State Islamic Institute of Tulungagung.

Bodgan, R. C., \& Biklen, S. (2007). Qualittaive Research for Education: An Introduction to Theory and Methods. Boston: Pearson.

Cutting, J. (2002). Pragmatics and Discourse. London: Routledge.

Islami, D. (2018). An analysis of Illocutionart Acts Used in Junior High School Students' "When English Rings The Bell" Grade VII. Thesis. Banda Aceh: Universitas Islam Negeri ArRaniry Banda Aceh.

Meirisa, Rasyid, Murtadho. (2017). Tindak Tutur Ilokusi Dalam Interaksi Pembelajaran Bahasa Indonesia (Kajian Etnografi Komunikasi di SMA Ehipassiko School BSD). BAHTERA: Jurnal Pendidikan Bahasa dan Sastra,16(2),1-14.

DOI: https://doi.org/10.21009/B AHTERA.162.01

Putri, E. A. (2019). Illocutionary Acts Used by Liz Gilbert in "Eat, Pray, Love" Movie. Thesis. Surabaya: State Islamic University of Sunan Ampel.

Rohmadi, Muhammad. 2004. Praktik Teori dan Analisis. Jogjakarta: Lingkar Media.

Rustono. (1999). Pokok-Pokok Pragmatik. Semarang: CV. IKIP Semarang Press.

Safira, J. (2017). An Analysis of Illocutionary Acts Used by Main Character in Zootopia Movie
Script. Thesis. Tulungagung: State Islamic Institute (IAIN).

Sari, R.I. (2017). Bentuk Tuturan Direktif Pada Guru Dalam Situasi Pembelajaran Bahasa Indonesia Siswa Kelas X MAN Malang 1. KEMBARA: Jurnal Keilmuan Bahasa, Sastra, dan Pengajarannya, 3(1), 79-97. DOI: https://doi.org/10.22219/ke mbara.v3i1.4380

Searle, J. (1979). Expression and Meaning Studies in The Theory of Speech Act. New York: Cambridge University Press.

Sefriana, M. (2019). An Analysis of Illocutionary Acts and Perlocutionary Acts in Movie "Monte Carlo" by Thomas Bezhuca. Thesis. Lampung: University of Islamic State Raden Intan Lampung.

Sembiring, W.A. (2019). Illocutionary Act on Aladdin Movie 2019. Journal BASIS, 6(2),277-283. DOI: https://doi.org/10.33884/ba sisupb.v6i2.1419

Siregar, D. M. (2018). A Study of Expressive Speech Act Used by The Characters in "Orphan" Movie Script. Thesis. Medan: University of Sumatera Utara.

Sudaryat, Y. (2009). Makna dalam Wacana. Bandung: CV. Yrama Widya.

Taufik, A. I. (2016). The Illocutionary Acts in Fast and Furious 7 Movie. Thesis. Jakarta: State Islamic University Syarif Hidayatullah Jakarta.

Yule, G. (1996). Pragmatic. New York: Oxford University Press.

Violeta, R. (2019). Speech Acts Analysis of The Main Character in Maleficent Movie Script by Jane McTee. Thesis. Lampung: University of Islamic State Raden Intan Lampung. 
